\title{
Direct Effects of Quality Management on Competitive Advantage
}

Ibrahim A Elshaer (University of Suez Canal) and Marcjanna M Augustyn (University of Hull)

\begin{abstract}
Purpose - This study examines direct effects of quality management on competitive advantage within the context of the resource based view of a firm.
\end{abstract}

Methodology - Survey data has been obtained from 288 general managers of luxury hotels in Egypt. We have used 6 dimensions and 22 indicators of quality management, two indicators of competitive advantage that manifest the hotel's above average financial performance relative to competitors within the study sample, and a multi-group analysis in structural equation modeling (SEM).

Findings - The results indicate that quality management may be a source of competitive advantage. Top management leadership and supplier management differentiate hotels with above average financial performance from its competitors. The role of customer focus and employee management in generating competitive advantage is questionable while process management and quality data and reporting may not contribute to achieving competitive advantage.

Research limitations/implications - Only direct effects of quality management on competitive advantage are examined within the context of a luxury hotel industry in Egypt. Similar studies within other contexts and models that study indirect effects of quality management on competitive advantage with factors that might moderate these effects are 
needed. Future studies could compare effects of quality management on competitive advantage with effects of quality management on other business outcomes.

Practical implications - The results may inform management decision making concerning the development of capabilities that may generate competitive advantage.

Originality/value - This study contributes to the debate on strategic value of quality management and resource-based sources of competitive advantage. Methodologically, this study shows an alternative approach to measuring competitive advantage and indicates that applying a multi-group analysis in SEM may contribute to producing original results.

\section{Keywords:}

Resource-based view (RBV), competitive advantage, performance, quality management, SEM

\section{Keywords:}

Resource-based view (RBV), competitive advantage, performance, quality management, SEM

\section{Paper type: Research paper}




\section{Introduction}

Many scholars agree that quality management may be a source of competitive advantage within the context of the resource based view (RBV) of a firm. From the theoretical perspective, this may occur if quality management is seen as a distinctive organizational capability embedded in the firm's business processes, organizational routines, knowledge, and skills (Wernerfelt, 1984; Rumelt, 1991; Teece et al., 1997; Tang and Liou, 2010; Yunis et al., 2013). RBV scholars argue that possession and effective exploitation of valuable and rare organizational resources and capabilities generates competitive advantage while inimitability and non-substitutability of these resources and capabilities will lead to sustaining this advantage (Newbert, 2008). Such strategic competencies (Thomas and Ryman, 2003) are associated with superior organizational performance (relative to competitors) that is achievable both in the short run and in the long run (Barney, 1991; Costa et al., 2013).

In his pioneering empirical work on quality management as a source of competitive advantage, Powell (1995) tested these theoretical assumptions and concluded within the limitations of his study that several quality management practices are associated with achieving competitive advantage. At the same time, however, Flynn et al. (1995) found no direct relationship between quality management and competitive advantage. Since then, only a few empirical studies have investigated the relationship between these two concepts despite calls for future research in this area expressed by several scholars (e.g. Sousa and Voss, 2002; Nair, 2006; Shenawy et al., 2007; Ebrahimi and Sadeghi, 2013). Our literature search within several academic databases returned only 23 articles with the keywords of 'quality management' and 'competitive advantage'. More articles were retrieved when using terms 'quality management' and 'performance' (349) but these studies rarely discussed their findings within the context of competitive advantage. 
A review of the scarce empirical work on direct effects of quality management on competitive advantage indicates three contradictory arguments. One of them holds that there is no direct relationship between these concepts and therefore quality management as such is not a source of competitive advantage (Flynn et al., 1995; Kaynak, 2003). Another argument says that quality management programs have to be implemented comprehensively to generate competitive advantage (Douglas and Judge, 2001), while a contrasting argument maintains that because only some quality management practices are positively associated with competitive advantage organizations may not need to focus on all practices to achieve competitive advantage (Powell, 1995; Dow et al., 1999). However, the few studies that found a direct association between these two concepts indicate that there is a lack of clarity concerning which quality management practices might generate competitive advantage.

The contradictory evidence emerging from the rare empirical studies that investigated the direct relationship between quality management and competitive advantage within broadly similar contexts of mainly U.S. and Australasian firms is therefore insufficient in supporting a view that quality management may be a source of competitive advantage within the context of the resource based view of a firm. As such, it provides little guidance to managers concerning their strategic choices.

In an attempt to advance our understanding of this problem, we have carried out a study aimed at testing the direct effects of quality management on competitive advantage within a different context to that of prior studies, i.e. the context of a highly competitive Egyptian luxury hotel industry. We have adopted a different methodological approach to prior studies with respect to measuring the independent and dependent variables. Firstly, recognizing that effects of quality management on competitive advantage may depend on the age of a quality management program (Powell, 1995; Corredor and Goni, 2011), we have used a scale that measures the length of time during which a quality management practice has 
existed in an organization. Secondly, given that competitive advantage is "above average performance in an industry" (Marcus, 2005, p.3) and thus differs from business performance per se (Powell, 2001; Newbert, 2008), we have measured competitive advantage as above average financial performance relative to competitors within the study sample. We have therefore used a multi-group analysis in structural equation modeling (SEM) and objective financial indicators to determine which quality management practices might generate competitive advantage relative to hotels with below average financial performance.

This paper presents the study findings and discusses them in relation to previous empirical work in this area. It therefore contributes to the debate on strategic value of quality management initiated by Powell (1995) and to advancing our knowledge of resource-based sources of competitive advantage, which according to several scholars (e.g. Newbert, 2008; Gruber et al., 2010) is supported by limited empirical evidence.

\section{Quality management as a source of competitive advantage}

Consistent with the RBV perspective, several scholars discussed the strategic potential of quality management, which integrates a set of complementary management practices intended to improve business performance mainly through achieving productivity and revenue gains (Deming, 1982; Garvin, 1984). Flynn et al. (1994) argued, for example, that quality management cannot be easily imitated by competitors because quality management practices continually improve and thus 'present a moving target' (p. 344) for the competitors. In his discussion of the strategic potential of total quality management (TQM), Powell (1995) provided a convincing theoretical argument that TQM may be imperfectly imitable, particularly when viewed from the diffusion of innovation and resource-based perspectives. He suggested that time compression diseconomies, connectedness of resources, causal ambiguity and social complexity make TQM imperfectly imitable. Powell (1995) also 
argued that the inimitability and non-substitutability of quality management may explain the frequently reported differences in business results achieved by firms that adopted TQM.

More recently, Reed et al. (2000) argued that the higher the complexity and tacitness of the key implementation processes, the more difficult it is for the competitors to copy them. Similarly, Escrig-Tena (2004) proposed that the valuable character of quality management may arise from an effective application of some of its practices that have potential to be developed into distinctive cross-functional competencies that may lead to greater productivity and revenue gains. As a management capability, quality management may therefore become a rare capability not because of its presence per se by because of the level of its effectiveness relative to competitors (Sirmon et al., 2010).

Some scholars attempted to test these theoretical assumptions by examining direct effects of various quality management practices on competitive advantage. While Flynn et al. (1995) and Kaynak (2003) found no direct relationship between quality management and competitive advantage, and while Douglas and Judge (2001) argued that it is the degree of comprehensiveness in implementing TQM programs that produces synergistic effect and generates competitive advantage, most scholars suggest that only some quality management practices may generate competitive advantage, albeit their views differ with regard to the types of advantage-generating practices. Our review of quality management and RBV literature indicates that there are six groups of quality management practices that have potential for generating competitive advantage, as discussed below.

Quality management literature suggests that that top management leadership is crucial to creating the environment and direction for continuous improvement (Phan et al., 2011; Ebrahimi and Sadeghi, 2013). Top management leadership acts as a driver of effective quality management implementation by creating goals, polices, values, and systems to fulfill stakeholder requirements that leads to improved business performance (Tari et al., 2007). 
According to RBV scholars, effective leadership as tacit and difficult to imitate capability may be a source of competitive advantage (Janson and McQueen, 2007; Douglas et al., 2012). Results of some empirical studies support this view. For example, Powell's (1995) tests of 39 U.S. manufacturing and service firms that employed over 50 people and that outperformed non-TQM firms uncovered that committed leadership as tacit, behavioral and inimitable aspects of quality management may be a source of the TQM firm's competitive advantage. More recently, Shenawy et al. (2007) carried out a meta-analysis of 51 studies and found that top management commitment/leadership was associated with competitive advantage. Similarly, in a study of 140 Queensland manufacturing, service and construction firms employing more than 16 people, Sharma and Gadenne (2008) found significant association between top management leadership and the firms' competitive position. We therefore hypothesize the following:

H1. Top management leadership has a significant positive effect on competitive advantage.

Several quality management scholars emphasize that employee management that focuses on employee involvement, empowerment, training and teamwork facilitates developing motivated, skillful and committed quality-minded employees, which leads to enhancing employee performance and satisfaction and to productivity and revenue gains (Sila and Ebrahimpour, 2005; Phan et al., 2011). Effective employee management is also viewed as a tacit management capability that facilitates organizational learning and development of employee behavior that can generate competitive advantage (Galbreath, 2005; Sirmon et al., 2011). Some empirical studies support this view. For example, Powell (1995) found a positive association between employee empowerment and perceived improved business performance while Shenawy et al. (2007) found positive association between teamwork and training/education and competitive advantage. More recently, in a longitudinal study of 336 
UK small and medium-sized enterprises, Sheehan (2014) found that human resource management has positive effect on sustained competitive advantage. We therefore hypothesize the following:

H2. Employee management has a significant positive effect on competitive advantage.

Literature also stresses the importance of customer focus in implementing quality management programs. Customer focus enables firms to effectively respond to the changing customer requirements which may lead to customer satisfaction (Yusuf et al., 2007). In addition, Escrig-Tena (2004) views customer focus as a distinctive competency that may be a source of increased brand loyalty that leads to greater sales and margins relative to competitors. Similarly, Bhatt and Emdad (2010) argue that customer focus is a valuable and inimitable dynamic capability that facilitates fast response to the changing customer requirements and effective product design that may lead to superior productivity and revenue gains. Some empirical studies support these theoretical assumptions and indicate that there is a positive relationship between customer focus and competitive advantage. For example, in an empirical study of 698 Australian/New Zealand manufacturing firms that employed over 20 people, Dow et al. (1999) found that customer focus has a positive significant relationship with superior quality outcomes. Similarly, in a study of 229 U.S. hospitals, Douglas and Judge (2001) found that customer focus is positively related to perceived organizational performance relative to competitors and to industry expert-rated performance. More recently, within the context of U.S. manufacturing and service firms, Bhatt and Emdad (2010) found that customer focus has positive impact on the firms' perceived competitive advantage. We therefore hypothesize the following:

H3. Customer focus has a significant positive effect on competitive advantage. 
Quality management scholars agree that supplier management encourages developing and maintaining active long-term relationships with the suppliers. It may therefore enhance supplier development, supply chain collaboration, integration and learning, stimulate product innovation and quality improvement and thus contribute to cost reduction and increased sales (Wagner, 2006; Mellat-Parast, 2012). Effective supplier management is also viewed as a dynamic capability that involves inter-organizational collaboration and learning and that may be a source of competitive advantage (Li et al., 2006; Allred et al., 2011). Empirical studies by Powell (1995) and Flynn et.al (1995) suggest that there may be a positive relationship between supplier management and competitive advantage, albeit results of their studies are inconclusive. Results of more recent studies in the field of supply chain management that were carried out in the U.S.A. show that supplier management may be a source of competitive advantage. Specifically, in a cross-sectional study of 196 organizations, Li et al. (2006) found that higher levels of supply chain management may lead to enhanced competitive advantage. Furthermore, in a longitudinal, multi-method research on supply chain collaboration, Allred et al. (2011) found a strong positive relationship between supplier management and firms' superior productivity. We therefore hypothesize the following:

\section{H4. Supplier management has a significant positive effect on competitive advantage.}

Quality management literature indicates that quality data and reporting inform decision making and may enhance quality awareness, identify quality problems and encourage further improvements that lead to cost reduction or greater sales (Wang et al., 2006; Ebrahimi and Sadeghi, 2013). Several scholars also argue that the distinctive capability of analyzing information and generating knowledge helps firms achieve the desired quality levels and generate competitive advantage (Rao et al., 1999; Berawi, 2004). Some empirical studies support these views. Douglas and Judge (2001) found, for example, that management 
by fact is positively related to perceived organizational performance relative to competitors and to industry expert-rated performance. More recently, Sharma and Gadenne (2008) found significant association between measurement/use of quality data and the firms' competitive position. We therefore hypothesize the following:

H5. Quality data and reporting has a significant positive effect on competitive advantage.

Numerous quality management scholars argue that process management may create organizational culture that reduces process duplication and variance, enhances reliability, eliminates production interruptions and thus results in achieving greater productivity gains and improved product quality that may lead to revenue gains (Wang et al., 2006; Phan et al., 2011). RBV scholars also suggest that effective process management as tacit and difficult to imitate capability that involves the interplay between managerial competencies and technical resources may be a source of competitive advantage (Wong et al., 2014). The results of Shenawy et al.'s (2007) meta-analysis indicate that process management may be associated with competitive advantage. More recently, based on results of a survey of 182 Malaysian manufacturing and service firms, Wong et al. (2014) concluded that effective process management may be a source of competitive advantage. We therefore hypothesize the following:

H6. Process management has a significant positive effect on competitive advantage.

\section{Methods}

\section{Sample}

Given the sampling limitations of prior studies and given that the value of resources is directly related to industry and market (Thomas and Ryman, 2003), we have set the following 
sampling criteria for the choice of study location and strategic group: new geographical and industrial study context, high level of competition within the selected strategic group, importance of quality management to the success of firms within the strategic group, and accessibility of data. Using these criteria, we have chosen Egypt as the location of the study because we could collect data there and because no study in this domain was previously done there. Furthermore, we have chosen the Egyptian luxury hotel industry because of the significant importance of quality to the hotels' success (Kandampully et al., 2011) and because it represents one of Egypt's most competitive industries with the majority of hotels (80\%) being operated by international chains (Egyptian Ministry of Tourism, 2010) and characterized by similar strategic characteristics that may impact upon industry profitability, including the extent of geographic coverage, service quality and pricing policy. We have obtained data for this study from a whole population of 384 four and five star hotels in Egypt.

A total of 300 respondents (130 from five star hotels and 170 from four star hotels) have returned a questionnaire that contained items measuring quality management and items measuring competitive advantage (see the following two sections for further details). Twelve uncompleted questionnaires (six from four star hotels and six from five star hotels) have been removed leaving 288 usable responses and yielding a response rate of 75 per cent. All questionnaires have been completed by the hotel general managers.

\section{Independent variables}

Literature review indicates that there are many approaches to managing quality, based for example on the TQM philosophy, the ISO 9001 standard or the criteria of various quality awards such as the Malcolm Baldrige National Quality Award and the EFQM Excellence Model. Although there are distinctive aspects characterizing each of the programs, they are all underpinned by similar principles derived from work of early quality management 
theorists such as W. Edwards Deming, Joseph Juran, and Kaoru Ishikawa. It is therefore unsurprising that our review of 127 empirical studies that measured quality management for various empirical purposes and that were published between 1989 and 2010 has identified practices that are common to most quality management programs.

For the purpose of this study, we have identified practices and dimensions that are most frequently covered in prior empirical studies and that are also embedded within the ISO 9000 quality management principles and within the criteria of several business excellence frameworks, such as the EFQM Excellence Model and the Baldrige Framework for Performance Excellence. Similar practices have been combined to create one category of practices. This process has generated six dimension of quality management, each described by several indicators. Following a review of these practices by three academics and 20 hotel managers, we have used 22 practices as indicators of quality management within six dimensions (see Table 1).

Since the effects of quality management on competitive advantage may depend on the age of a quality management program (Powell, 1995; Corredor and Goni, 2011), we have used a continuous scale to measure the length of time during which a quality management practice existed in a hotel.

\section{Dependent variables}

Given that competitive advantage refers to "above average performance in an industry" (Marcus, 2005, p.3) and thus differs from business performance per se (Powell, 2001; Newbert, 2008), we define competitive advantage as achieving above average financial performance relative to the firm's competitors in its industry. However, this definition raises two questions: which firms are competitors, and how to measure above average financial performance. In this study, we have used Porter's (1980) strategic group analysis to identify 
Table 1. Quality management dimensions and indicators

\begin{tabular}{|c|c|}
\hline $\begin{array}{l}\text { Quality management } \\
\text { dimensions }\end{array}$ & Indicators \\
\hline Top management leadership & $\begin{array}{l}\text { X1: Provision of the necessary financial resources to implement quality } \\
\text { management related practices. } \\
\text { X2: Availability of an established quality planning process. } \\
\text { X3: Evaluating results by comparing them to planned results. }\end{array}$ \\
\hline Employee management & $\begin{array}{l}\text { X4: Involvement of all departments in quality related activities. } \\
\text { X5: Training in statistical techniques. } \\
\text { X6: Discussing employee quality related suggestions at a monthly inter } \\
\text { departmental meeting. } \\
\text { X7: Implementing quality related suggestions. } \\
\text { X8: Creating work environment that encourages employees to perform to } \\
\text { the best of their abilities. }\end{array}$ \\
\hline Customer focus & $\begin{array}{l}\text { X9: Contact with customers to be updated about their requirements. } \\
\text { X10: Contact with customers to update them about new products. } \\
\text { X11: Considering customer requirements in the product design process. } \\
\text { X12: Studying results of customer satisfaction surveys. } \\
\text { X13: Having an effective process for resolving customer complaints in a } \\
\text { timely manner. }\end{array}$ \\
\hline Supplier management & $\begin{array}{l}\text { X14: Establishing long-term relationships with high reputation suppliers. } \\
\text { X15: Providing suppliers with a clear specification of the required } \\
\text { product. } \\
\text { X16: Consideration of supplier capabilities in the product design process. }\end{array}$ \\
\hline Quality data and reporting & $\begin{array}{l}\text { X17: Displaying quality data (defects and errors rates; control charts) in } \\
\text { most departments. } \\
\text { X18: Using quality data to evaluate employee performance. } \\
\text { X19: Displaying progress towards quality related goals. }\end{array}$ \\
\hline Process management & $\begin{array}{l}\text { X20: Giving employees standardized instructions about their task. } \\
\text { X21: Using statistical techniques to reduce variance in processes. } \\
\text { X22: Using a preventive maintenance system. }\end{array}$ \\
\hline
\end{tabular}

industry direct competitors because it enables identifying firms with similar strategic characteristics, such as factors that impact upon industry profitability, the extent of geographic coverage, product quality and pricing policy. Competitive advantage is therefore measured here as above average financial performance relative to the firm's direct rivals. Consistent with Peteraf and Barney's (2003) view that competitive advantage creates more economic value in terms of either operating at lower costs than competitors or in terms of achieving greater benefits than competitors and consistent with theories on the impact of 
quality management practices on business performance (Deming, 1982; Garvin, 1984), we have used two objective financial measures that are appropriate for the context of this study: employee productivity (i.e. the mean of the hotel total revenue for the last three years divided by the hotel number of employees) and revenue per room (i.e. the mean of the hotel total revenue for the last three years divided by the hotel number of rooms). The above average employee productivity (EP) and the above average revenue per room (RpR) within the study sample are therefore considered here as indicators of competitive advantage.

To identify hotels that achieve competitive advantage within the study sample, we have calculated the sampled hotels' average performance on these two variables and for each dependent variable (i.e. EP and RpR) we have split the study data into two groups: (1) hotels with above average performance (i.e. hotels with competitive advantage) and (2) hotels with below average performance (i.e. hotels without competitive advantage). We have then analyzed significant structural differences between these groups of hotels, as discussed in the following section.

\section{Analytical methods}

We have used Cronbach's alpha and the Corrected Item -Total Correlation (CITC) to assess internal consistency of the measures. To test construct convergent and discriminant validity, we have used confirmatory factor analysis (CFA). Three criteria have been selected to assess convergent validity: factor loadings, composite reliability and average variance extracted (AVE). We have assessed discriminant validity by comparing the AVE value for any two constructs with the square of the correlation estimates between the same two constructs. The variance extracted estimates should be greater than the squared correlation estimates to have evidence of discriminant validity. To detect and control any potential common method variance, we have used post hoc Harman single factor analysis where all research variables 
(dependent and independent) are entered in SPSS for exploratory factor analysis (EFA) and the number of factors extracted is constrained to one with no rotation method. However, Podsakoff et al. (2003) argue that Harman's test is insensitive and there is no clear guideline as to what should be the satisfactory percentage of explained variance of a single-factor model. Therefore, to support the results of the Harman single factor analysis test, we have used CFA to compare the model fit of two models, where the first model allows all research items (independent and dependent) to measure on factor and the second model allows all items (independent and dependent) to load on their theoretical constructs. If common method variance is largely responsible for the relationship among the variables, the first model should fit the data better than the second model (Podsakoff et al., 2003).

Using structural equation modeling (SEM), we have tested the hypothesized relationships between the research variables and whether or not the structural models (paths of the causal structure) are equivalent (i.e. invariant) across multi-groups of hotels (i.e. hotels with competitive advantage measured by above average financial performance and hotels without competitive advantage measured by below average financial performance). We have used SEM because of its unique ability to combine factor analysis and linear regression to simultaneously test complex dependence relationships between the study's latent multidimensional constructs and because of its ability to test whether or not the paths of the causal structure are equivalent (i.e. invariant) between hotels with and without competitive advantage (Byrne, 2010).

To assess a structural models' goodness of model fit (GOF), we have used the following measures: (a) measures of absolute fit: $\chi 2 / \mathrm{df}$, standardized root mean square residual (SRMR), and Root Mean Square Error of Approximation (RMSEA); (b) measures of incremental fit: Comparative Fit Index (CFI), and Normed Fit Index (NFI); and (c) measures 
of parsimony fit : Parsimony Comparative Fit Index (PCFI) and Parsimony Normed Fit Index (PNFI) (Byrne, 2010).

To examine which quality management practices can generate competitive advantage, we have identified two models: the first one investigates the effects of quality management on employee productivity (EP) and the second model investigates the effects of quality management on revenue per room (RpR). To identify statistically significant differences between hotels with and without competitive advantage as well as path coefficients that cause the significant differences, we have used a multi-group analysis in SEM where the first group included hotels with competitive advantage (measured by above average financial performance) and the second group included hotels without competitive advantage (measured by below average financial performance). Given that we have used two measures of financial performance (EP and RpR), we have tested four models in SEM in order to identify their goodness of fit: (1) a model testing effects of quality management on above average EP; (2) a model testing effects of quality management on below average EP; (3) a model testing effects of quality management on above average RpR; and (4) a model testing effects of quality management on below average RpR. We have used the multi-group analysis to find out whether or not the structural models (paths of the causal structure) are equivalent (i.e. invariant) across the two groups of interest (i.e. hotels with competitive advantage as measured by achieving above average financial performance within the study sample and hotels without competitive advantage as measured by achieving below average financial performance within the study sample). We have compared the goodness of model fit values of a configural (baseline) model against a constrained structural weights model. If the $\chi^{2}$ difference value between the configural model and the structural weights constrained model is statistically significant at a probability of less than 0.001 , it can be concluded that one or more of the structural paths coefficients is not operating equivalently across the two groups 
(Byrne, 2010). The hypothesis of invariance across the group of interest is rejected when CFI difference $(\triangle \mathrm{CFI})$ value is greater than -0.01 (Cheung and Rensvold, 2002).

\section{Results}

All necessary conditions to run a CFA and SEM (that is conditions regarding the sample size, missing data, outliers, normality, and multicollinerity) have been met, as discussed below.

Following rules of thumb, our study sample size of 288 is adequate for SEM tests because: (a) it meets Nunnally's (1967) requirement of a minimum 10 respondents per item (our instrument contains 24 indicators so our the sample size exceeds the required sample size of 240); (b) it meets Boomsma's (1982) requirement of sample size based on the ratio of indicators $(p)$ to latent variables $(k)$, which in this study is 3.42 (24 indicators $/ 7$ constructs) and therefore requires sample size of at least 200, (c) it meets Hair et al.'s (2006) requirement of a minimum sample size of 100-150 to obtain stable maximum likelihood estimation (MLE) solutions. Nevertheless, it is important to highlight that no rule of thumb can be applied generally to all situation in SEM and that sample size requirements may substantially vary (Wolf et al., 2013). This is because the appropriate sample size in SEM depends on many other factors including the variables' psychometric properties, the strength of the relationships between the variables considered, the model size and complexity, the amount of missing data, the distributional characteristics of the variables, and the estimation method used (Raykov and Marcoulides, 2006; Kline,2011). Iacobucci (2010) notes, for example, that "SEM models can perform well, even with small samples (e.g. 50 to 100)" (p. 92).

Therefore, although the sub-sample sizes for multi-group analysis in our study are smaller (ranging from 111 to 113 for hotels with competitive advantage, and from and 175 to 177 for hotels without competitive advantage), they are considered as adequate for the purpose of this 
study because (1) they are both larger than the minimum satisfactory sample size of 100 subjects for conducting SEM (Ding et al., 1995), (2) they meet Bentler and Chou's (1987) requirement of five subjects per variable for normal and elliptical distributions when the latent variables have multiple indicators, and (3) they meet the requirement of the recommended minimum sample size sample of 100-150 for obtaining stable MLE results (Hair et al., 2006).

We have also tested the adequacy of the complete sample and subsamples following the data collection process using the one-sample Z-test method (Montgomery, 2004, cited in Aranda, et al., 2012) and online sample Size Calculator (Statistical Solutions, 2015). As indicated in Table 2, the sizes of the complete study sample and subsamples used in the multi-group analysis are adequate for the purpose of this study because they either exceed or are equal to the required sample sizes for alpha 0.05 and power 0.80 .

Table 2. One-sample Z-test (two-sided) for adequacy of the study's complete sample size and sub-sample sizes.

\begin{tabular}{|r|r|r|r|r|r|}
\hline $\begin{array}{l}\text { Actual } \\
\text { sample size }\end{array}$ & $\begin{array}{l}\text { Required } \\
\text { sample size } \\
\text { for alpha } \\
\text { 0.05 }\end{array}$ & $\begin{array}{l}\text { Known } \\
\text { mean value }\end{array}$ & $\begin{array}{l}\text { Expected } \\
\text { mean value }\end{array}$ & $\begin{array}{l}\text { Known } \\
\text { standard } \\
\text { deviation }\end{array}$ & \multicolumn{1}{l|}{ Power } \\
\hline $\mathrm{N}=288$ & $\mathrm{~N}=41$ & 4.2 & 5.0 & 1.82 & 0.80 \\
\hline $\mathrm{N}=113$ & $\mathrm{~N}=70$ & 4.5 & 5.0 & 1.49 & 0.80 \\
\hline $\mathrm{N}=175$ & $\mathrm{~N}=10$ & 3.5 & 5.0 & 1.63 & 0.80 \\
\hline $\mathrm{N}=111$ & $\mathrm{~N}=111$ & 5.4 & 5.0 & 1.50 & 0.80 \\
\hline $\mathrm{N}=177$ & $\mathrm{~N}=11$ & 3.5 & 5.0 & 1.70 & 0.80 \\
\hline
\end{tabular}

We have subsequently tested the adequacy of the complete sample and subsamples using Cohen's (1988) formula and PASS 13 software (NCSS, 2015). This test shows that the required sample sizes for this study range from $\mathrm{N}=27$ to $\mathrm{N}=106$ depending on the value of the required $\mathrm{R}^{2}$ (see Table 3). For example, a sample size of 106 achieves $81 \%$ power to detect an $\mathrm{R}^{2}$ of 0.20 attributed to 22 independent variables using an F-Test with a significance 
level (alpha) of 0.05 . This test further supports the adequacy of the sizes of the complete sample and subsamples for the purpose of this study because the actual sample sizes range from 111 to 288 and exceed all of the required sample size values presented in Table 3.

Table 3. Cohen's (1988) test for adequacy of the study's complete sample size and subsample sizes.

\begin{tabular}{|c|c|c|c|c|c|c|}
\hline \multirow[t]{2}{*}{ Power } & \multirow[t]{2}{*}{ Beta } & \multicolumn{2}{|c|}{$\begin{array}{c}\text { Independent variables } \\
\text { tested }\end{array}$} & \multicolumn{2}{|c|}{$\begin{array}{c}\text { Independent variables } \\
\text { controlled }\end{array}$} & \multirow{2}{*}{$\begin{array}{l}\text { Required } \\
\text { sample } \\
\text { size for } \\
\text { alpha } 0.05\end{array}$} \\
\hline & & Number & $\begin{array}{l}R^{2} \text { added to the } \\
\text { overall } R^{2} \text { value } \\
\text { by the variables }\end{array}$ & Number & $\begin{array}{l}R^{2} \text { added to the } \\
\text { overall } R^{2} \text { value } \\
\text { by the variables }\end{array}$ & \\
\hline .81 & .194 & 22 & .20 & 0 & .00 & $\mathrm{~N}=106$ \\
\hline .81 & .194 & 22 & .30 & 0 & .00 & $\mathrm{~N}=70$ \\
\hline .81 & .186 & 22 & .40 & 0 & .00 & $\mathrm{~N}=53$ \\
\hline .82 & .178 & 22 & .50 & 0 & .00 & $\mathrm{~N}=43$ \\
\hline .81 & .190 & 22 & .60 & 0 & .00 & $\mathrm{~N}=36$ \\
\hline .83 & .170 & 22 & .70 & 0 & .00 & $\mathrm{~N}=32$ \\
\hline .85 & .151 & 22 & .80 & 0 & .00 & $\mathrm{~N}=29$ \\
\hline .91 & .087 & 22 & .90 & 0 & .00 & $\mathrm{~N}=27$ \\
\hline
\end{tabular}

We have checked the current study for missing data using the SPSS package and we have found a lot of missing values randomly occurring in 12 out of 300 questionnaires (less than 5\%). We have decided to exclude these questionnaires as they can cause dramatic effects on the research results (Hair et al., 2006). Therefore, we have used 288 valid questionnaires in this study.

We have used boxplot in the SPSS package and we have found an outlier in variable number 14 (“establishing long-term relationships with high reputation suppliers"). However, because the value is within the ordinary range of values but unique in the combination of values across the variables, we have retained it as per Hair et al.'s (2006) recommendation. We have also found outliers within the financial performance variables. However, these outliers are expected because normally some hotels might have higher financial performance than others. 
To test normality of the complete sample and sub-samples, we have inspected skewness and kurtosis values as well as shapes of distributions using a histograms, and Normal Q-Q Plots in SPSS. Since none of the variables in our samples have problematic levels of skew or kurtosis and most of the shapes do not depart from the normality assumption, non-normality is not an issue in this study (Tabachnick and Fidell, 2007).

With regard to multicollinearity, the positive relationships between variables have been confirmed by checking the correlation coefficient in SPSS. The values of Pearson $r$ between variables range from 0.35 to and 0.86 and no correlation is more than 0.9 , which indicates that there is no multicollinearity between the variables (Tabachnick and Fidell, 2007).

\section{Test for reliability and validity}

Composite Cronbach's alpha values for the six factors that measure quality management reflect satisfactory internal consistency for those items. The reliability scores of all averaged scales of top management leadership, employee management, customer focus, supplier management, quality data and reporting, and process management exceed 0.91 , which is above the usual cut-off level of 0.7 as recommended by Nunnally and Bernstein (1994). Internal reliabilities of each construct range from 0.83 to 0.95 , all exceeding the minimum criterion of 0.60 (Bagozzi and $\mathrm{Yi}, 1988$ ). Moreover, the results of CITC range from 0.82 to 0.95 and are well above the threshold of 0.4 as recommended by Nunnally and Bernstein (1994).

The results of testing convergent and discriminant validity of the measurement model indicate that there is no negative error variance and that no standardized parameter estimation exceeds the value of one. Therefore, there is no estimation problem and no identification problem related to negative variances, as discussed below. 
Table 4. Convergent validity of the study constructs

\begin{tabular}{|c|c|c|c|c|c|c|c|c|c|c|}
\hline & $\mathbf{F L}$ & $\begin{array}{c}\text { Unsta. } \\
\text { Est. }\end{array}$ & S.E. & C.R.**** & Err. & E.Est & S.E. & C.R.**** & $\begin{array}{l}\text { Composite } \\
\text { reliability (CR) }\end{array}$ & $\begin{array}{l}\text { Average variance } \\
\text { extracted (AVE) }\end{array}$ \\
\hline Top management leaderaship (TML) & & & & & & & & & \multirow[t]{4}{*}{0.805} & \multirow[t]{4}{*}{0.91} \\
\hline $\mathrm{X} 14-\cdots \mathrm{TML}$ & 0.89 & 1.00 & & & e1 & 0.70 & 0.079 & $8.976^{* * *}$ & & \\
\hline $\mathrm{X} 24----\mathrm{TML}$ & 0.93 & 1.05 & 0.043 & $24.500^{* * *}$ & e2 & 0.49 & 0.068 & $7.226^{* * *}$ & & \\
\hline X3 ४----TML & 0.91 & 1.06 & 0.045 & $23.600^{* * *}$ & e3 & 0.61 & 0.076 & $8.094^{* * *}$ & & \\
\hline \multicolumn{9}{|l|}{ Employee management (EM) } & \multirow[t]{6}{*}{0.834} & \multirow[t]{6}{*}{0.89} \\
\hline $\mathrm{X} 4$ ४-ー-ー- EM & 0.88 & 1.000 & & & e4 & 0.76 & 0.077 & $9.927^{* * *}$ & & \\
\hline $\mathrm{X} 5 \bullet-----\mathrm{EM}$ & 0.90 & 1.080 & 0.048 & $22.630^{* * *}$ & e5 & 0.67 & 0.073 & $9.191^{* * *}$ & & \\
\hline X6 ४----- EM & 0.89 & 1.000 & 0.046 & $21.810^{* * *}$ & e6 & 0.69 & 0.072 & $9.672^{* * *}$ & & \\
\hline $\mathrm{X} 7 \bullet-----\mathrm{EM}$ & 0.88 & 0.992 & 0.047 & $21.120^{* * *}$ & e7 & 0.75 & 0.076 & $9.944^{* * *}$ & & \\
\hline X8 4-----EM & 0.90 & 1.240 & 0.051 & $22.180^{* * *}$ & e8 & 0.78 & 0.083 & $9.480^{* * *}$ & & \\
\hline \multicolumn{9}{|l|}{ Customer focus (CF) } & \multirow[t]{6}{*}{0.845} & \multirow[t]{6}{*}{0.904} \\
\hline X9 $4----C F$ & 0.89 & 1.000 & & & e9 & 0.86 & 0.087 & $9.968 * * *$ & & \\
\hline $\mathrm{X} 10 \triangleleft---\mathrm{CF}$ & 0.91 & 0.954 & 0.040 & $23.673 * * *$ & e10 & 0.65 & 0.069 & $9.461 * * *$ & & \\
\hline $\mathrm{X} 11 \triangleleft----\mathrm{CF}$ & 0.92 & 0.997 & 0.041 & $24.317 * * *$ & e11 & 0.62 & 0.069 & $9.138 * * *$ & & \\
\hline $\mathrm{X} 12 \leftarrow----\mathrm{CF}$ & 0.90 & 0.978 & 0.042 & $23.199 * * *$ & e12 & 0.74 & 0.076 & $9.703 * * *$ & & \\
\hline $\mathrm{X} 13$ ४----CF & 0.90 & 1.031 & 0.045 & $23.028 * * *$ & e13 & 0.86 & 0.088 & $9.808 * * *$ & & \\
\hline \multicolumn{9}{|l|}{ Supplier management (SM) } & \multirow[t]{4}{*}{0.817} & \multirow[t]{4}{*}{0.883} \\
\hline X14 ४---- SM & 0.79 & 1.000 & & & e14 & 0.89 & 0.083 & $10.755^{* * *}$ & & \\
\hline $\mathrm{X} 154----\mathrm{SM}$ & 0.91 & 1.124 & 0.062 & $18.141 * * *$ & e15 & 0.41 & 0.054 & $7.723 * * *$ & & \\
\hline $\mathrm{X} 16 \leftarrow---\mathrm{SM}$ & 0.95 & 1.351 & 0.070 & $19.291 * * *$ & e16 & 0.27 & 0.062 & $4.421 * * *$ & & \\
\hline \multicolumn{9}{|l|}{ Quality data and reporting (QD\&R) } & \multirow[t]{3}{*}{0.813} & \multirow[t]{3}{*}{0.93} \\
\hline X17 4-- QD\&R & 0.90 & 1.000 & & & e17 & 0.84 & 0.088 & $9.582^{* * *}$ & & \\
\hline $\mathrm{X} 18<---\mathrm{QD} \& \mathrm{R}$ & 0.93 & 1.025 & 0.039 & $26.574^{* * *}$ & e18 & 0.57 & 0.072 & $8.007^{* * *}$ & & \\
\hline X19 4-- QD\&R & 0.96 & 1.069 & 0.037 & $28.647^{* * *}$ & e19 & 0.37 & 0.065 & $5.826^{* * *}$ & \multirow{5}{*}{0.805} & \multirow{5}{*}{0.926} \\
\hline Process management (PM) & & & & & & & & & & \\
\hline X20 4-ー- PM & 0.92 & 1.000 & & & e20 & 0.70 & 0.082 & $8.662^{* * *}$ & & \\
\hline $\mathrm{X} 214----\mathrm{PM}$ & 0.93 & 1.001 & 0.036 & $27.960^{* * *}$ & e21 & 0.57 & 0.073 & $7.797^{* * *}$ & & \\
\hline $\mathrm{X} 22 \leftarrow--ー P M$ & 0.93 & 1.007 & 0.036 & $27.631^{* * *}$ & e22 & 0.60 & 0.076 & $7.914^{* * *}$ & & \\
\hline
\end{tabular}

X1-X22: variables that measure the study constructs; FL-Factor loading; U.Est.: Unstandardized regression estimates; SE: standard error; CR: Critical Ratio; E.Est.: error variance estimates; $* * * \mathrm{P}<0.001$ 
The first indicator of each construct (X1, X4, X9, X14, X17, and X20) has a fixed regression weight of 1.00 resulting in no associated standard error or critical ratio. As shown in Table 4, the critical ratios associated with the other indicators are all significant at the 0.001 level. With respect to the previously mentioned three criteria of convergent validity, all study constructs meet all of them. Specifically, all factor loading values exceed the cut-off point of 0.7 (they range from 0.79 to 0.96 ) which shows a high degree of a positive relationship among scale items developed to measure each of the study constructs. Secondly, the composite reliability values range from 0.805 to 0.845 and are above the cut-off point 0.8 which indicates that the heterogeneous (but similar) indicators that measure each of the study construct have an overall good reliability. Thirdly, the average variance extracted values range from 0.89 to 0.93 and exceed the cut-off value of 0.5 which reflects a good overall amount of variance in the manifest variables accounted for by the latent construct. Overall, the convergent validity results confirm that the measures of constructs that should be theoretically related are in reality related.

The results of discriminant validity test indicate that the average variance extracted estimates for all constructs are greater than the squared correlation estimates (see Table 5), which confirms discriminant validity of all constructs.

The results of Harman's single factor method show that the factor that emerged from this analysis explains 41 percent of the variance. This indicates that common method variance is not a major concern in this study. These results are supported by results of CFA that compared the model fit of two models: a model where all variables (dependent and independent) are allowed to measure only one factor and a model where all items (independent and dependent) are allowed to load on their theoretical constructs. The model fit indices in Figure 1 show that the second model fits the data better than the first model, which 
indicates that common method variance is not responsible for the relationship among the research variables.

Table 5. Squared Correlation Estimates and AVE*

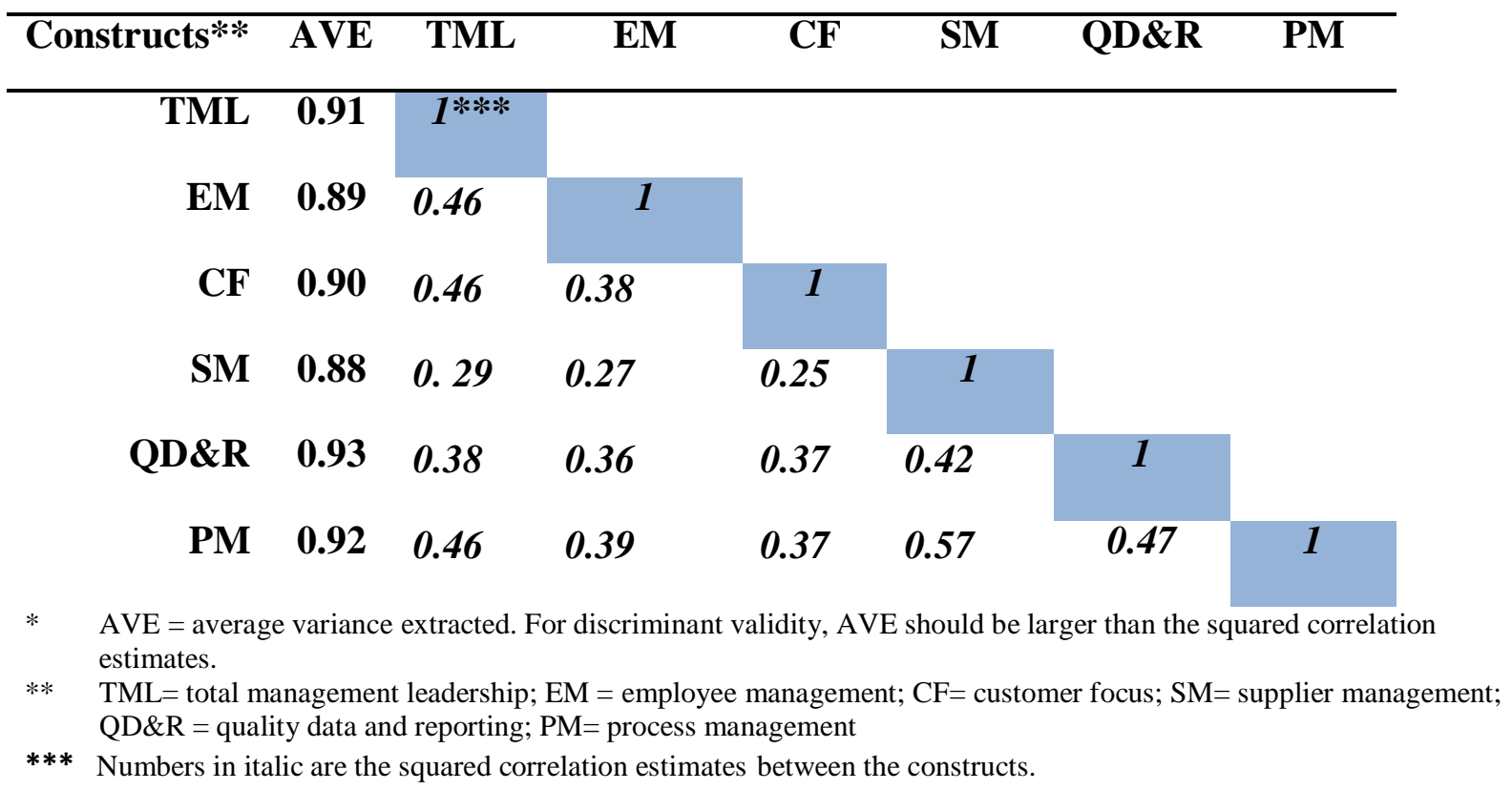

\section{SEM results}

The SEM results of testing the four models that we have used to examine relationships between research variables show that models that test the effects of quality management on competitive advantage (measured by above average $\mathrm{EP} / \mathrm{RpR}$ ) fit the data better than models that test the effects of quality management on below average EP/RpR (see Table 6).

Specifically, the GOF statistics indicate that models 1 and 3 fit the data better than models 2 and 4.

The results of the equivalence (invariance) test for the models that measure quality management and above/below average employee productivity indicate that the hypothesis of invariance across the two groups of interest can be rejected. Indeed, the CFI difference $(\Delta \mathrm{CFI})$ value $(0.011)$ exceeds the cut-off value of -0.01 and the $\chi^{2}$ difference $\left(\Delta \chi^{2}\right)$ value (88.123 with 28 degrees of freedom) is statistically significant at a probability of less than 


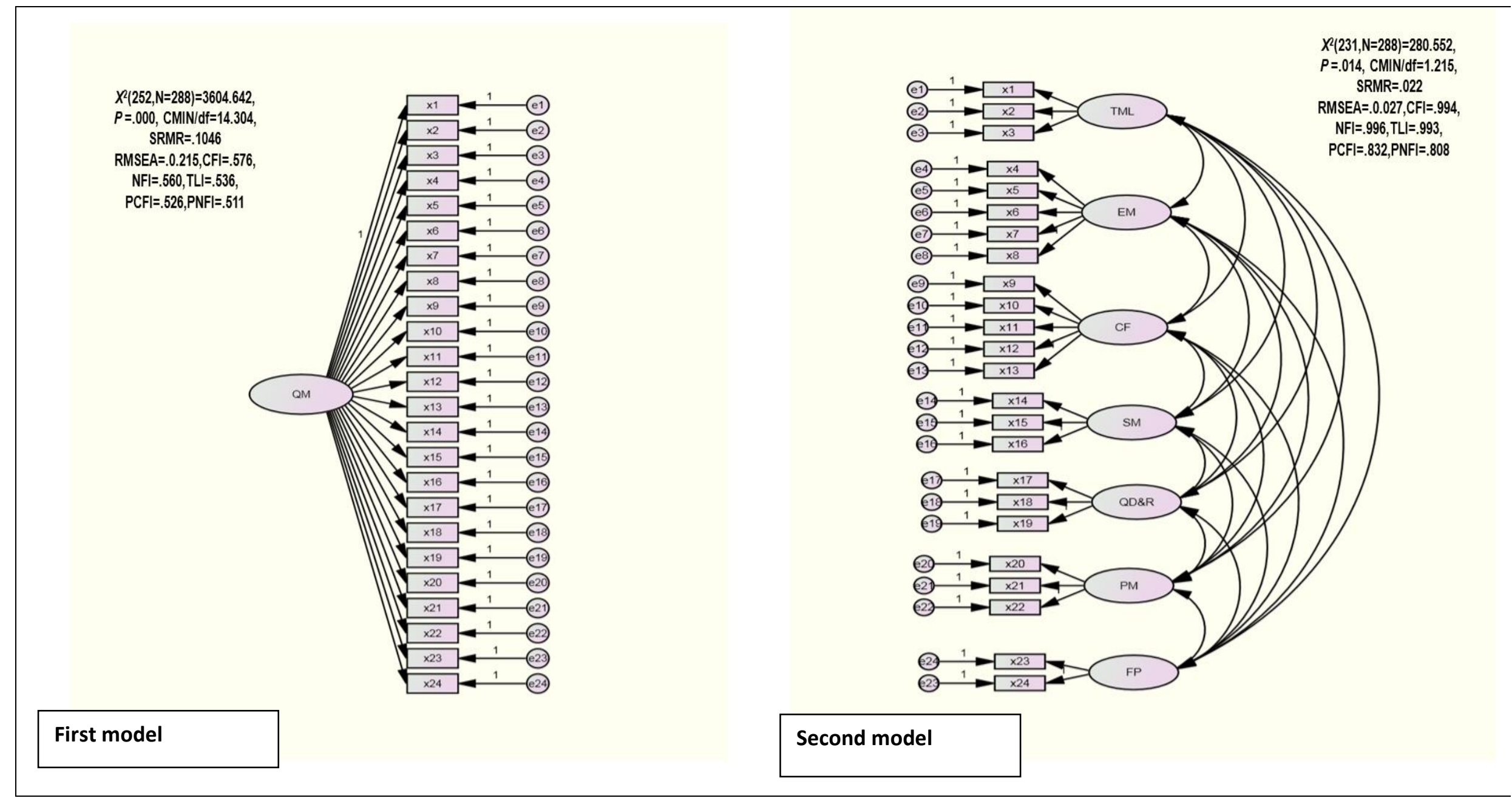

Figure 1: Common method variance two model comparison 
Table 6. Summary of model fit indices for above average employee productivity (EP) and revenue per room $(\mathrm{RpR})$ and below average EP and RpR models.

\begin{tabular}{|c|c|c|c|c|c|c|c|c|}
\hline & & \multicolumn{3}{|c|}{$\begin{array}{c}\text { AFM } \\
\text { absolute fit measures }\end{array}$} & \multicolumn{2}{|c|}{$\begin{array}{c}\text { IFM } \\
\begin{array}{c}\text { incremental fit } \\
\text { measures }\end{array} \\
\end{array}$} & \multicolumn{2}{|c|}{$\begin{array}{c}\text { PFM } \\
\text { parsimony fit measures }\end{array}$} \\
\hline & $\begin{array}{l}\chi^{2} \text { and probability } \\
\text { value }\end{array}$ & $\chi^{2 / d f}$ & RMSEA & SRMR & CFI & NFI & PNFI & PCFI \\
\hline $\begin{array}{r}\text { Standard fit } \\
\text { values }\end{array}$ & & $\leq 3$ & $\begin{array}{r}\leq 0.05 ; \leq \\
0.08\end{array}$ & $<0.08$ & $\geq 0.90$ & $\geq 0.90$ & $>0.5$ & $>0.5$ \\
\hline $\begin{array}{l}\text { Model 1: } \\
\text { impact of QM on } \\
\text { above average } \\
\text { EP (CA) }\end{array}$ & $\begin{array}{r}\chi 2(225, \mathrm{~N}=113)= \\
363.807, \mathrm{P}<0.001\end{array}$ & 1.617 & 0.047 & 0.070 & 0.932 & 0.923 & 0.748 & 0.829 \\
\hline $\begin{array}{l}\text { Model 2: impact } \\
\text { of QM on below } \\
\text { average EP }\end{array}$ & $\begin{array}{r}\chi 2(225, \mathrm{~N}=175)= \\
784.417, \mathrm{P}<0.001\end{array}$ & 3.846 & 0.050 & 0.078 & 0.900 & 0.910 & 0.714 & 0.755 \\
\hline $\begin{array}{l}\text { Model 3: impact } \\
\text { of QM on above } \\
\text { average RpR } \\
\text { (CA) }\end{array}$ & $\begin{array}{c}\chi 2(225, \mathrm{~N}=111)= \\
349.763, \mathrm{P}<0.001\end{array}$ & 1.555 & 0.049 & 0.075 & 0.937 & 0.929 & 0.753 & 0.750 \\
\hline $\begin{array}{l}\text { Model 4: impact } \\
\text { of QM on below } \\
\text { average RpR }\end{array}$ & $\begin{array}{l}\chi 2(225, \mathrm{~N}=177)= \\
811.419, \mathrm{P}<0.001\end{array}$ & 3.606 & 0.050 & 0.078 & 0.905 & 0.901 & 0.753 & 0.713 \\
\hline
\end{tabular}

$\mathrm{QM}=$ quality management; $\mathrm{CA}=$ competitive advantage

0.001 (see Table 7). Consequently, the results of the multi-group analysis show that the full structural model (i.e. path coefficient) is completely non-equivalent across the two groups of interest (i.e. above/below average EP). Therefore, there are some paths in the models which cause this variance. In other words, there are some paths in the model that can explain the reasons behind this variance and indicate which quality management practices differentiate the model that tests the effect of quality management on competitive advantage (measured by above average $\mathrm{EP}$ ) from the model that tests the effect of quality management on below average EP.

Table 7. Goodness-of fit measures for the configural and constrained models (QMPs on EP)

\begin{tabular}{|c|r|r|r|r|r|}
\hline Model & CMIN & DF & P & CMIN/DF & CFI \\
\hline Unconstrained (configural model) & 1147.953 & 450 & 0.000 & 2.551 & 0.923 \\
\hline Structural weights & 1236.076 & 478 & 0.000 & 2.585 & 0.912 \\
\hline
\end{tabular}


Similarly, the results of the equivalence test for the models that measure quality management and above/below average revenue per room indicate that the hypothesis of invariance across the two groups of interest can be rejected too because the CFI difference $(\Delta \mathrm{CFI})$ value $(0.006)$ exceeds the cut-off value of -0.01 and the $\chi^{2}$ difference $\left(\Delta \chi^{2}\right)$ value (61.596 with 23 degrees of freedom) is statistically significant at a probability of less than 0.001 (see Table 8). Consequently, the results of the multi-group analysis once again show that the full structural equation model (i.e. paths coefficient) is completely non-equivalent across the two groups of interest (above /below average RpR) and that there are some paths in the model that can explain the reasons behind this variance and indicate which quality management practices differentiate the model that tests the effect of quality management on competitive advantage (measured by above average $\mathrm{RpR}$ ) from the model that tests the effect of quality management on below average $\mathrm{RpR}$.

Table 8. Goodness-of fit measures for the configural and constrained models (QMPs on RpR)

\begin{tabular}{|c|r|r|r|r|r|}
\hline Model & CMIN & DF & P & CMIN/DF & CFI \\
\hline Unconstrained (configural model) & 1160.853 & 450 & 0.000 & 2.580 & 0.937 \\
\hline Structural weights & 1222.449 & 473 & 0.000 & 2.584 & 0.931 \\
\hline
\end{tabular}

The SEM results presented in Figures 2 and 3 show that two quality management practices, quality data and reporting and process management, may not generate competitive advantage. Specifically, there is evidence that quality data and reporting has an insignificant negative effect on above average $\mathrm{EP}$ (path coefficient $=-0.01, \mathrm{P}=0.892$ ) and has an insignificant negative effect on above average $\mathrm{RpR}$ (path coefficient $=-0.15, \mathrm{P}=0.12$ ). Similarly, there is evidence that quality data and reporting has an insignificant negative effect on below average $\mathrm{EP}$ (path coefficient $=-0.10, \mathrm{P}=0.24$ ), and has an insignificant negative effect on below average $\mathrm{RpR}$ (path coefficient $=-0.11, \mathrm{P}=0.27$ ). The results also show that 
process management has a significant negative effect on above average EP (path coefficient $=-0.23, \mathrm{P}<0.05$ ), and a significant negative effect on above average $\mathrm{RpR}$ (path coefficient $=$ $-0.20, \mathrm{P}<0.05)$. However, process management has a significant positive effect on below average EP (path coefficient $=0.27, \mathrm{P}<0.05$ ), and an insignificant positive effect on below average $\mathrm{RpR}$ (path coefficient $=0.19, \mathrm{P}=0.094$ ).

The SEM results also indicate that two other quality management practices, customer focus and employee management, have a significant positive effect both on competitive advantage and on below average financial performance. In detail, the results indicate that employee management has a significant positive effect on above average $\mathrm{EP}$ (path coefficient $=0.22, \mathrm{P}<0.05$ ), and a significant positive effect on above average $\mathrm{RpR}$ (path coefficient $=$ $0.19, \mathrm{P}<0.05)$. Similarly, employee management has a significant positive effect on below average $\mathrm{EP}$ (path coefficient $=0.20, \mathrm{P}<0.05$ ) and a significant positive effect on below average RpR (path coefficient $=0.29, \mathrm{P}<0.01$ ). Additionally, the SEM results indicate that customer focus has a significant positive effect on above average $\mathrm{EP}$ (path coefficient $=0.21$, $\mathrm{P}<0.05$ ), and a significant positive effect on above average $\mathrm{RpR}$ (path coefficient $=0.27$, $\mathrm{P}<0.01)$. Similarly, customer focus has a significant positive effect on below average EP (path coefficient $=0.41, \mathrm{P}<0.001$ ), and a significant positive effect on below average $\mathrm{RpR}$ (path coefficient $=0.42, \mathrm{P}<0.001)$.

The SEM results also indicate that two quality management practices, top management leadership and supplier management, differentiate hotels with competitive advantage from hotels without competitive advantage. In detail, the results of the SEM show that top management leadership has a significant positive effect on above average EP (path coefficient $=0.41, \mathrm{P}<0.001)$ and a significant positive effect on above average $\mathrm{RpR}$ (path coefficient $=0.34, \mathrm{P}<0.001)$. Similarly, supplier management has a significant positive effect on above average $\mathrm{EP}$ (path coefficient $=0.24, \mathrm{P}<0.05$ ), and a significant positive effect on 


\section{Model (1) QM and above average EP (CA)}

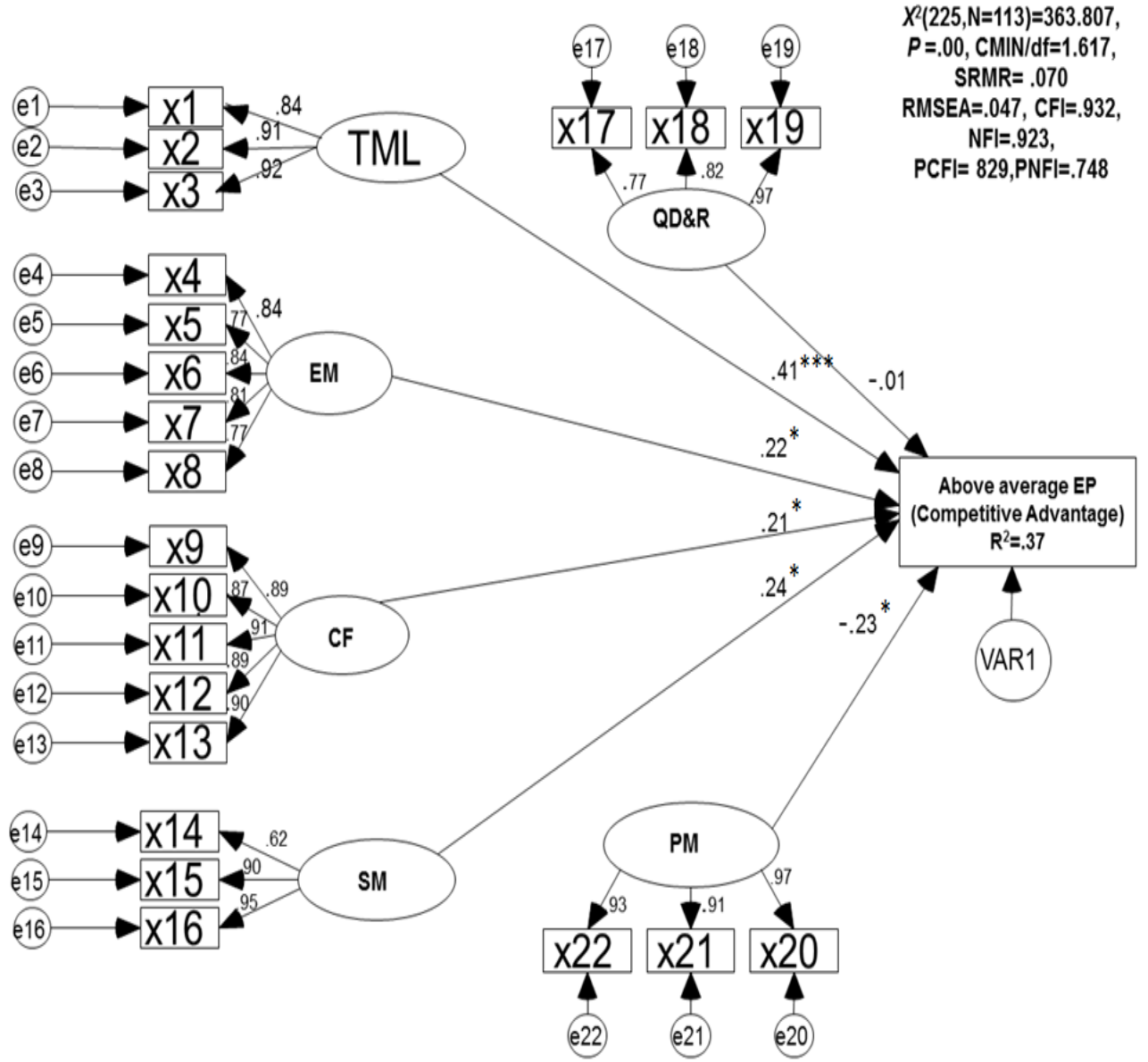

\section{Model (2) QM and below average EP}

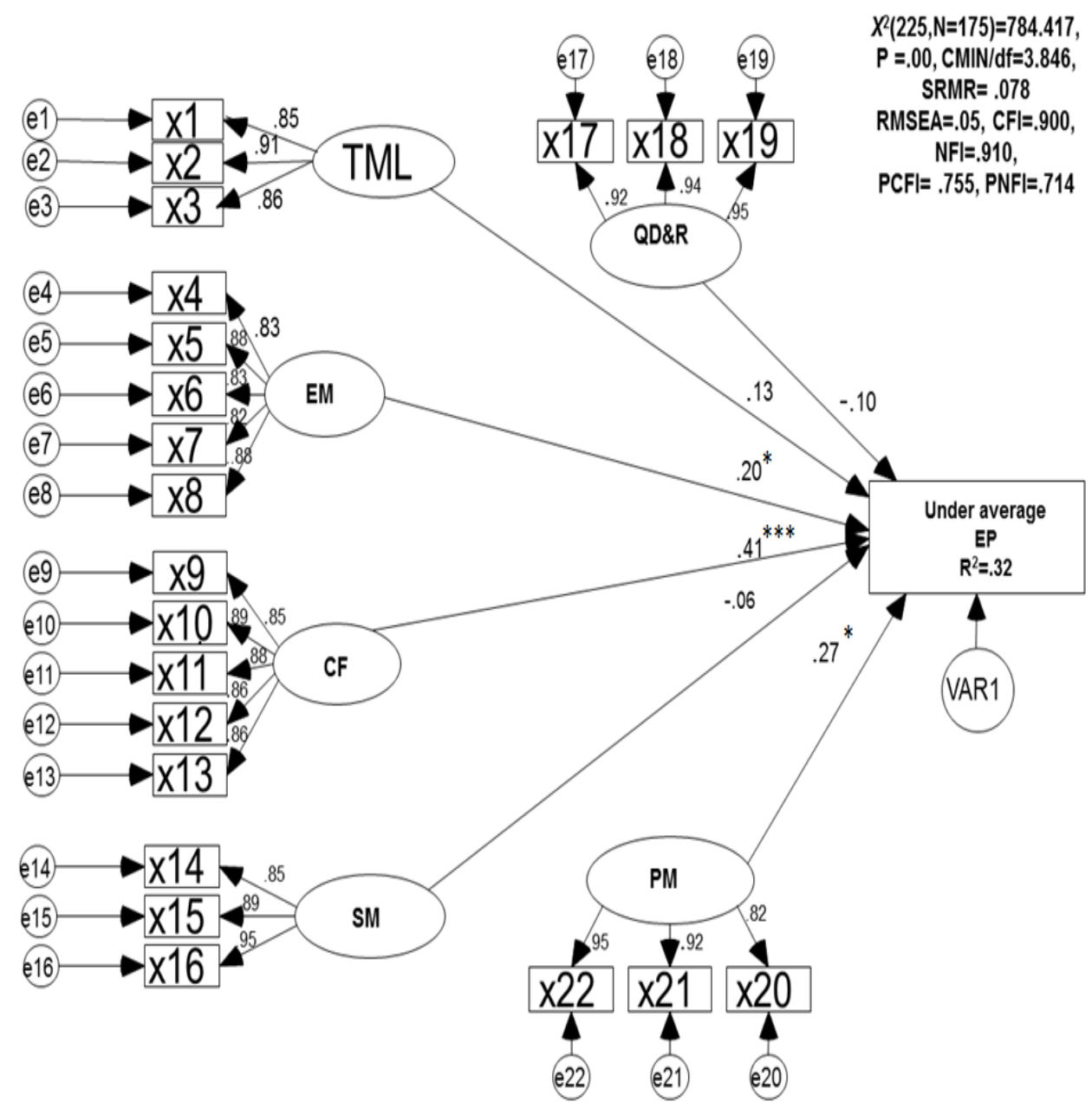

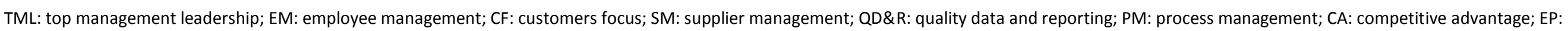

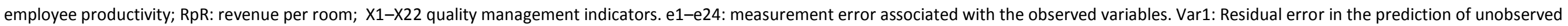

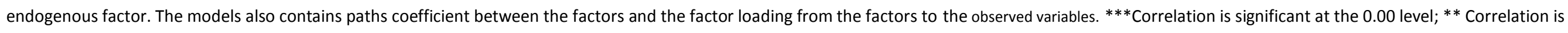
significant at the 0.01 level; * Correlation is significant at the 0.05 level.

Figure 2: Quality management and competitive advantage: structural model 1 and 2 


\section{Model (3) QM and above average RpR (CA)}

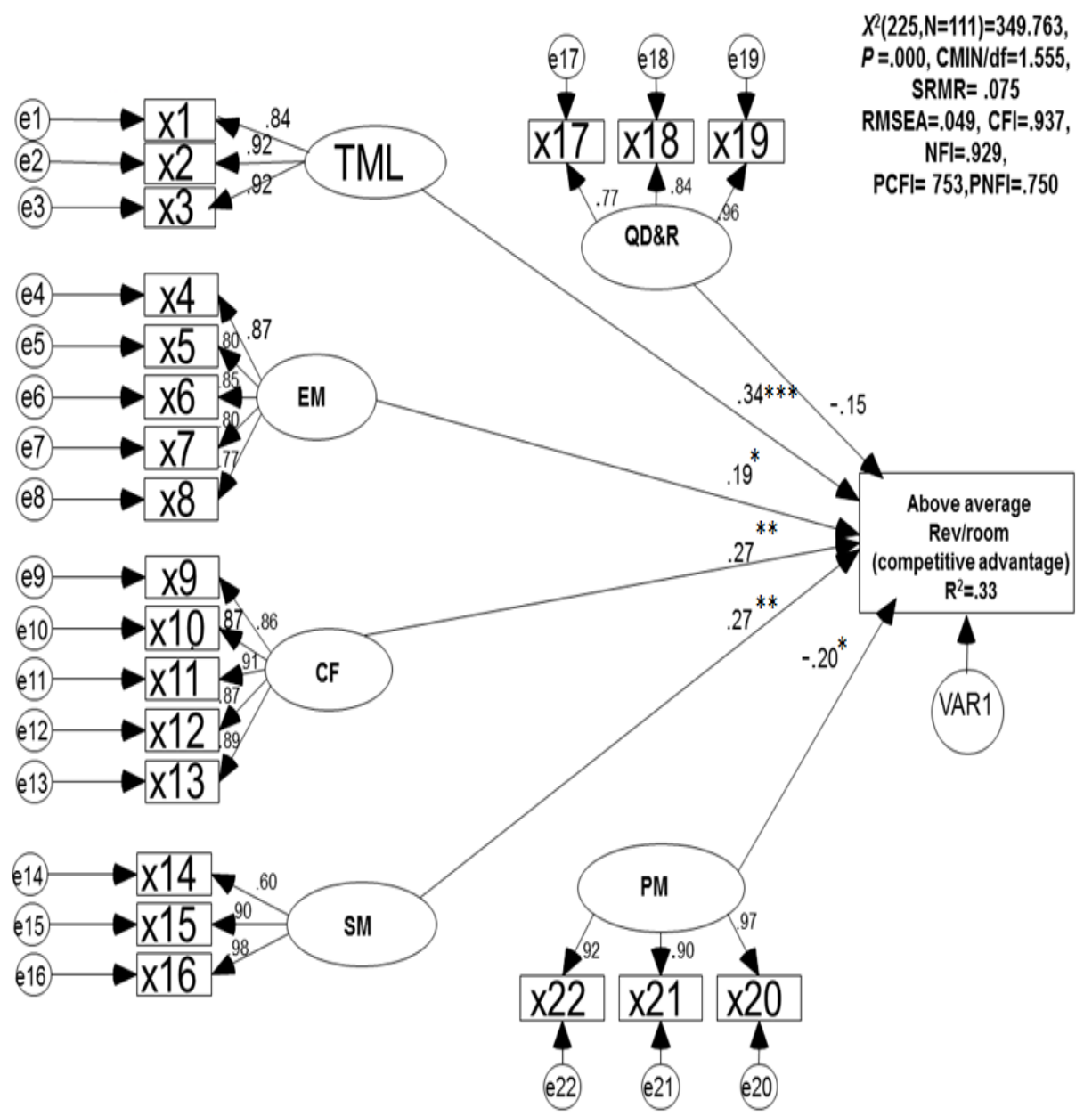

Model (4) QM and below average RpR

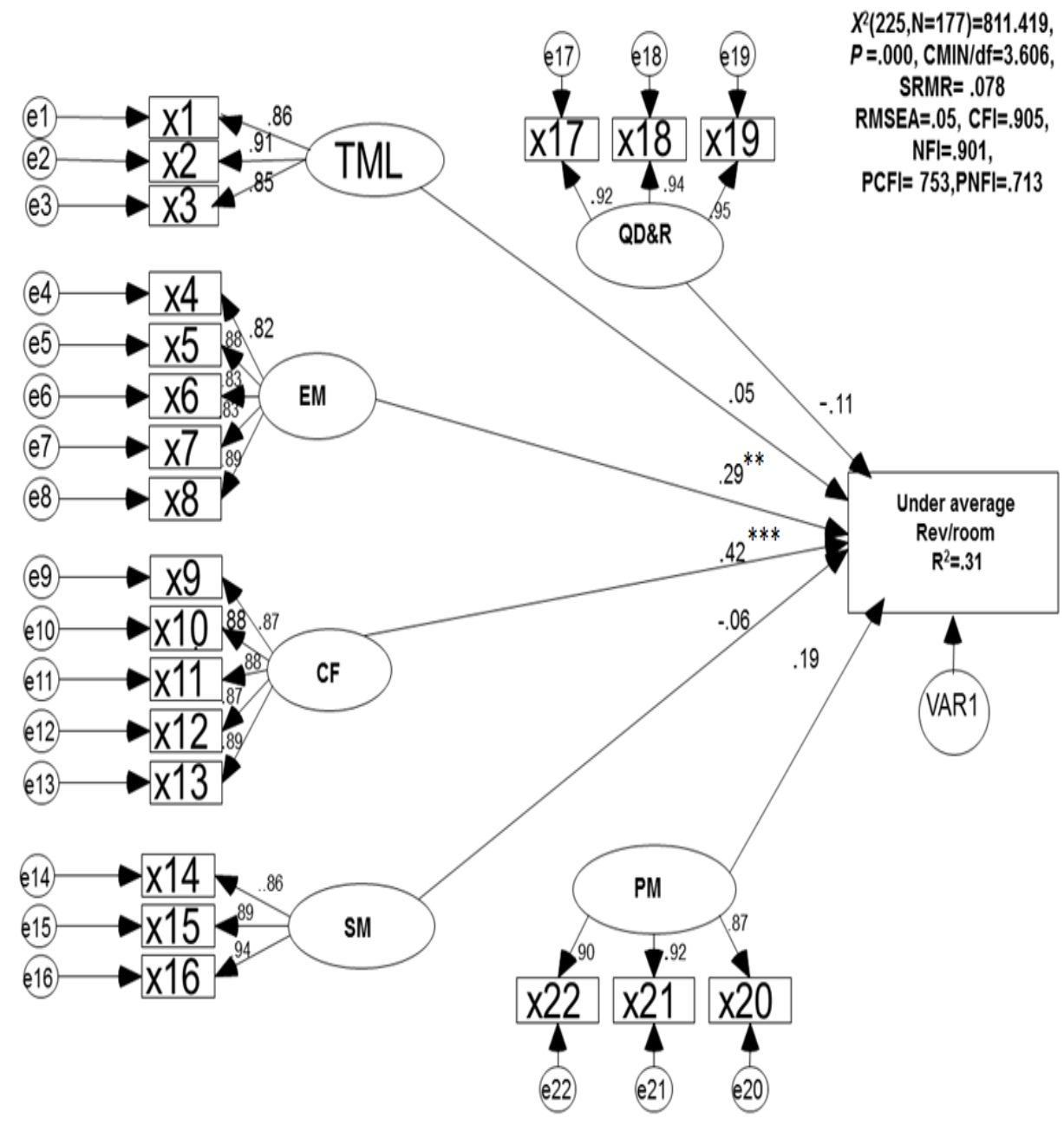

TML: top management leadership; EM: employee management; CF: customers focus; SM: supplier management; QD\&R: quality data and reporting; PM: process management; CA: competitive

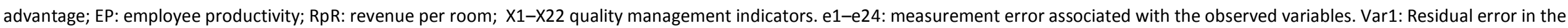
prediction of unobserved endogenous factor. The models also contains paths coefficient between the factors and the factor loading from the factors to the observed variables. ${ }^{* * *}$ Correlation is significant at the 0.00 level; ${ }^{* *}$ Correlation is significant at the 0.01 level; * Correlation is significant at the 0.05 level.

Figure 3: Quality management and competitive advantage: structural model 3 and 4 
above average $\mathrm{RpR}$ (path coefficient $=0.27, \mathrm{P}<0.01$ ). On the other hand, the SEM results show that top management leadership has a small insignificant positive effect on below average $\mathrm{EP}$ (path coefficient $=0.13, \mathrm{P}=0.161$ ) and a very small insignificant positive effect on below average $\mathrm{RpR}$ (path coefficient $=0.05, \mathrm{P}=0.58$ ). Furthermore, supplier management has an insignificant negative effect on below average $\mathrm{EP}$ (path coefficient $=-0.06, \mathrm{P}=0.53$ ) and an insignificant negative effect on below average $R p R$ (path coefficient $=-0.06, P=0.55$ ).

\section{Model validation}

Bootstrap maximum likelihood has been performed in a number of 1000 bootstrap samples with 95 percentile confidence interval. This technique bootstraps the original data to reproduce multiple subsamples and create bootstrap estimates and standard errors. The bootstrap estimator and related confidence interval are employed to decide how stable the sample statistic is as an estimate of the whole population (Byrne, 2010)

There are no large differences between the original data parameter estimates, standard error, and $\mathrm{P}$ values, and the bootstrap estimates and standard error of the bootstrapped data indicate that the differences are very small. Additionally, the data indicate that the bias difference between the bootstrap mean estimate and the original sample estimate is very small. Therefore, the results can be interpreted as being stable estimates of the whole population.

\section{Discussion and Conclusion}

This study has examined direct effects of quality management on competitive advantage with a view to ascertaining whether quality management may be a source of competitive advantage within the context of the resource based view of a firm. Specifically, since the effects of quality management on competitive advantage may depend on the age of 
a quality management program (Powell, 1995; Corredor and Goni, 2011), we have measured the length of time during which quality management practices have existed in an organization and their effect on competitive advantage measured by above average hotel financial performance relative to its direct competitors within the study sample.

The results of the multi-group analysis in structural equation modeling show that both models that test the effects of quality management on above average employee productivity and revenue per room (as indicators of competitive advantage) fit the data better than the two models that test the effects of quality management on below average employee productivity and revenue per room. This indicates that quality management may be a source of competitive advantage.

A comparative analysis of path coefficients for the four models tested in this study suggests that while keeping all mediating effects constant, variation in competitive advantage is mainly determined by two factors: top management leadership and supplier management. Indeed these two factors have the strongest significant positive effect on competitive advantage relative to other factors. At the same time these two factors have small insignificant effect on below average financial performance, which further supports the hypotheses that top management leadership and supplier management may generate competitive advantage.

The comparative analysis of path coefficients also indicates that two factors, customer focus and employee management, demonstrate significant positive effects upon both the above average and below average financial performance. However, customer focus has a much stronger effect on below average financial performance than on competitive advantage. Relative to top management leadership, both customer focus and employee management have much weaker positive effects on competitive advantage and much stronger positive effects on below average financial performance. In fact, customer focus has the greatest effect on 
financial performance of hotels with below average financial performance. Relative to supplier management, employee management has a slightly weaker effect on competitive advantage and a much stronger effect on below average financial performance. The findings question therefore the role of customer focus and employee management in generating competitive advantage.

The final two factors, process management and quality data and reporting, may not contribute to attaining competitive advantage. Indeed, while quality data and reporting has a small insignificant negative effect on competitive advantage, process management has a moderate significant negative effect on competitive advantage thus potentially inhibiting its attainment. In contrast, process management is the second strongest factor that determines variations in financial performance of hotels with below average financial performance.

The results of our study contradict two prior arguments that our literature review has revealed, i.e. the argument that holds that there is no direct relationship between quality management and competitive advantage (Flynn et al., 1995; Kaynak, 2003), and the argument that says that quality management programs have to be implemented comprehensively to generate competitive advantage (Douglas and Judge, 2001). However, the results of our study support the third argument that maintains that only some quality management practices are sources of competitive advantage (Powell, 1995; Dow et al., 1999).

With regard to the prior lack of clarity concerning which quality management practices might generate competitive advantage within the context of the resource based view of the firm, the results of our study enhance our understanding of this problem in the following ways.

Firstly, similarly to earlier empirical findings concerning the relationship between quality management and competitive advantage (e.g. Powell, 1995; Dow et al., 1999; 
Shenawy et al., 2007) our results indicate that top management leadership could be a source of competitive advantage. Additionally, the use of multi-group analysis in structural equation modeling has enabled us to demonstrate that top management leadership has relatively the strongest direct effect on competitive advantage. This is an important finding that not only supports the view that top management leadership may generate competitive advantage but it also shows, for the first time, that this may be the most important source of competitive advantage within the framework of quality management. This finding supports therefore the view that top management leadership may be a valuable and rare organizational capability that generates competitive advantage (e.g. Powell, 1995, Sharma and Gadenne, 2008).

Secondly, unlike earlier empirical findings in the field of quality management (Powell, 1995; Dow et al, 1999) that provided inconclusive evidence concerning the role of relationships with suppliers in attaining competitive advantage, this study similarly to the emergent results of studies in the field of supply chain management (Li et al., 2006; Allred et $a l ., 2011)$ directs our attention to the importance of supplier management in explaining variations in competitive advantage and indicates that supplier management may be a valuable and rare organizational capability within the framework of quality management that generates competitive advantage.

Thirdly, our findings concerning the role of customer focus and employee management challenge theoretical arguments and results of prior empirical studies that emphasize the importance of these practices in achieving competitive advantage (e.g. Reed et al., 2000; Escrig-Tena, 2004; Bhatt and Emdad; 2010; Sirmon et al., 2011; Sheehan, 2014). They may also partially explain the contradictory results of earlier empirical studies that investigated the strategic value of customer focus and employee management within the framework of quality management (e.g. Powell, 1995; Dow et al., 1999; Shenawy et al., 
2007). Indeed, the use of multi-group analysis in structural equation modeling has enabled us to demonstrate, for the first time, that these two groups of practices have positive significant effects on both hotels with competitive advantage and hotels without competitive advantage. Consequently, while these practices may be important in enhancing firm performance per se they may not be of strategic importance in relation to other quality management practices that have shown such a potential in this study.

Fourthly, our results challenge theoretical assumptions and results of prior empirical studies (e.g. Douglas and Judge, 2001; Berawi, 2004; Sharma and Gadenne, 2008; Wong et $a l ., 2014)$ that suggest that process management and quality data and reporting may generate competitive advantage. Instead, our results support findings of earlier empirical studies (e.g. Powell, 1995; Dow et al., 1999) that suggest that technical, non-behavioral aspects of quality management may not generate competitive advantage. Indeed, the results of multi-group analysis employed in our study indicate that process management and quality data and reporting may not contribute to the attainment of competitive advantage. In addition, process management has been found, for the first time, to have a negative significant effect on competitive advantage thus potentially inhibiting its attainment.

The results of this study also contribute to advancing our knowledge of resourcebased sources of competitive advantage, which according to several scholars (e.g. Newbert, 2008; Gruber et al., 2010) is supported by limited empirical evidence. Indeed, the results of this study challenge the view that customer focus and employee management are distinctive capabilities and as such may generate competitive advantage. In addition, it shows that two factors, top management leadership and supplier management may generate competitive advantage. While the general contribution of top management leadership to attaining competitive advantage has been supported by some empirical evidence, less is known about supplier management as a strategic competency. This study may therefore open new areas for 
empirical investigation particularly with regard to supplier management, customer focus and employee management as sources of competitive advantage.

In addition to the theoretical contribution outlined above, this study has also methodological and practical value. Methodologically, this study shows an alternative approach to measuring competitive advantage as above average financial performance relative to the firm's direct competitors within the study sample. This study shows that the approach of splitting the study sample into hotels with and without competitive advantage (as measured by their above/below average financial performance respectively) and the application of multi-group analysis in structural equation modeling may produce unique, previously unknown insights concerning effects of various factors on competitive advantage. Adopting similar methodology in other studies may therefore enhance our understanding of sources of competitive advantage within the context of the resource based view of the firm.

From the practical perspective, the findings of this study may inform management decision making concerning the development of capabilities that may generate competitive advantage. Specifically, they may draw management attention to top management leadership and supplier management as likely sources of competitive advantage within the quality management framework.

It should be noted, however, that study has investigated only direct effects of quality management on competitive advantage using relatively small subsamples in the multi-group analysis drawn from one industry and one country only. Although the sample sizes are adequate for the purpose of this study, future studies could use larger samples drawn from a wider variety of industries or countries and also test models that examine indirect effects of quality management on competitive advantage. An analysis of such relationships within wider geographical and industrial contexts could provide further insights into the role of quality management as a strategic competence. Furthermore, since other factors that may 
affect competitive advantage have been held constant in this study, future studies could investigate the various factors that moderate the effects of quality management on competitive advantage. Future studies could also consider adopting a longitudinal research design that could provide a deeper understanding of the effects of quality management on competitive advantage. Finally, given that this study has investigated direct effects of quality management on competitive advantage only future studies could compare effects of quality management on competitive advantage with effects of quality management on other business outcomes. This would greatly enhance our understanding of the effects of quality management on a variety of business outcomes.

\section{References}

Allred, C.R., Fawcett, S.E., Wallin, C. and Magnan, G.M. (2011), “A dynamic collaboration capability as a source of competitive advantage", Decision Sciences, Vol. 42, pp. 129-161.

Aranda, A., Ferreira, G., Mainar-Toledo, M.D., Scarpellini, S., Sastresa, E.L. (2012), "Multiple regression models to predict the annual energy consumption in the Spanish banking sector", Energy and Buildings, Vol. 49, pp. 380-387.

Bagozzi, R.P and Yi, Y. (1988), "On the evaluation of structural equation models", Journal of the Academy of Marketing Science, Vol. 16 No.4, pp. 74-94.

Barney, J.B. (1991), "Firm resources and sustained competitive advantage", Journal of Management, Vol. 17, pp. 99-120.

Bentler, P.M. and Chou, C. (1987), "Practical issues in structural equation modeling", Sociological Methods and Research, Vol. 16, pp. 78-117.

Berawi, M.A. (2004), "Quality revolution: leading the innovation and competitive advantages", International Journal of Quality \& Reliability Management, Vol. 21, pp. 425-438.

Bhatt, G.D. and Emdad, A.F. (2010), "An empirical examination of the relationship between information technology (IT) infrastructure, customer focus, and business advantages", Journal of Systems and Information Technology, Vol. 12, pp. 4-16.

Boomsma, A. (1982), "The robustness of LISREL against small sample sizes in factor analysis models", in J"oreskog, K.G. and Wold, H. (Eds.), Systems under Indirect Observation: Causality, Structure, Prediction. Part I, North-Holland, Amsterdam, pp. 149173.

Byrne, B. (2010), Structural Equation Modelling: Basic Concepts, Applications, and Programming. Lawrence Erlbaum Associates, London.

Cheung, G.W. and Rensvold, R.B. (2002), "Evaluating goodness-of-fit indexes for testing measurement invariance", Structural Equation Modeling, Vol. 9, pp. 233-255. 
Cohen, J. (1988), "Statistical Power Analysis for the Behavioral Sciences", Lawrence Erlbaum Associates, Hillsdale, New Jersey.

Corredor, P. and Goni, S. (2011), “TQM and performance: Is the relationship so obvious?", Journal of Business Research, Vol. 64, pp. 830-838.

Costa, L.A., Cool, K. and Dierickx, I. (2013), "The competitive implications of the deployment of unique resources", Strategic Management Journal, Vol. 34, pp. 445-463.

Deming, W.E. (1982), Quality, Productivity and Competitive Position, MIT Centre for Advanced Engineering, Cambridge, MA.

Ding, L., Velicer, W.F. and Harlow, L.L. (1995), "Effects of estimation methods, number of indicators per factor, and improper solutions on structural equation modeling fit indices", Structural Equation Modeling: A Multidisciplinary Journal, Vol. 2, pp. 119-143.

Douglas, D., Jenkins, W. and Kennedy J. (2012), "Understanding continuous improvement in an English local authority", International Journal of Public Sector Management, Vol. 25, pp.17-33.

Douglas, T.J. and Judge, W.Q. (2001), "Total quality management implementation and competitive advantage: The role of structural control and exploration", The Academy of Management Journal, Vol. 44, pp. 158-169.

Dow, D., Samson, D. and Ford, S. (1999), "Exploding the myth: do all quality management practices contribute to superior quality performance?", Production and Operations Management, Vol. 8, pp. 1-27.

Ebrahimi, M. and Sadeghi, M. (2013), "Quality management and performance: An annotated Review", International Journal of Production Research, Vol. 51, pp. 5625-5643.

Egyptian Ministry of Tourism, (2010), Egyptian Hotel Guide. Egypt.

Escrig-Tena, A.B. (2004), "TQM as a competitive factor: A theoretical and empirical Analysis", International Journal of Quality and Reliability Management, Vol. 21, pp. 612637.

Flynn, B.B, Schroeder, R.G. and Sakakibara, S. (1994), “A framework for quality management research and associated measurement instrument", Journal of Operations Management, Vol. 11, pp. 339-366.

Flynn, B.B, Schroeder, R.G. and Sakakibara, S. (1995), "The impact of quality management practices on performance and competitive advantage", Decision Sciences, Vol. 26, pp. 659-691.

Galbreath, J. (2005), "Which resources matter the most to firm success? An exploratory study of resource-based theory", Technovation, Vol. 25, pp. 979-987.

Garvin, D. (1984), "What does product quality really mean?" Sloan Management Review, Vol. 26, pp. 25-43.

Gruber, M., Heinemann, F., Brettell, M. and Hungeling, S. (2010), "Configurations of resources and capabilities and their performance implications. An exploratory study of technology ventures", Strategic Management Journal, Vol. 31, pp. 1337-1356.

Hair, J.F., Black, B., Babin, D., Anderson, R.E. and Tatham, R. (2006), Multivariate Data Analysis, Prentice Hall, London.

Iacobucci, D. (2010), "Structural equations modeling: Fit indices, sample size, and advanced topics", Journal of Consumer Psychology, Vol. 20, pp. 90-98.

Janson, A. and McQueen, R.J. (2007), "Capturing leadership tacit knowledge in conversations with Leaders", Leadership \& Organization Development Journal, Vol. 28, pp. 646-663.

Kandampully, J., Juwaheer, T.D. and Hu, H.H. (2011), “The influence of a hotel firm's quality of service and image and its effect on tourism customer loyalty", International Journal of Hospitality \& Tourism Administration, Vol.12, pp. 21-42. 
Kaynak, H. (2003), "The relationship between total quality management practices and their effects on business performance", Journal of Operations Management, Vol. 34 No 2, pp. $1-31$.

Kline, R.B. (2011), Principles and Practice of Structural Equation Modelling, Guilford Press, New York, NY.

Li, S., Ragu-Nathan, B., Ragu-Nathan, T.S., and Rao, S.S. (2006), "The impact of supply chain management practices on competitive advantage and organizational performance", Omega, Vol. 34, 107-124.

Marcus, A.A. (2005), Management Strategy: Achieving Sustained Competitive Advantage. McGraw-Hill Companies, Singapore.

Mellat-Parast, M. (2012), "Supply chain quality management. An inter-organizational learning perspective", International Journal of Quality \& Reliability Management, Vol. 30, pp. 511-529.

Montgomery, G.C.R.D.C. (2004), Probabilidad y Estadística Aplicadas a la Ingeniería, Wiley, Mexico D.F.

Nair, A. (2006), "Meta-analysis of the relationship between quality management practices and business performance-implications for quality management theory development", Journal of Operations Management, Vol. 24, pp. 948-975.

NCSS (2015), "PASS 13 Sample Size", http://www.ncss.com/software/pass/

Newbert, S.L. (2008), "Value, rareness, competitive advantage and performance: a conceptual level empirical investigation of the resource-based view of the firm", Strategic Management Journal, Vol. 29., pp. 745-768.

Nunnally, J.C. (1967), Psychometric Theory, McGraw Hill, New York, NY.

Nunnally, J.C. and Bernstein I.H. (1994), Psychometric Theory, McGraw Hill, New York, NY.

Peteraf, M.A. and Barney, J. (2003), "Unraveling the resource-based tangle", Managerial and Decision Economics, Vol. 24, pp. 309-323.

Phan, A.C., Abdallah, A.B. and Matsui, Y. (2011) "Quality management practices and competitive performance: empirical evidence from Japanese manufacturing companies", International Journal of Production Economics, Vol. 133, pp. 518-529.

Podsakoff, P., MacKenzie, S., Lee J.Y. and Podsakoff, N. (2003), "Common method bias in behavioral research: A critical review of the literature and recommended remedies", Journal of Applied Psychology, Vol. 88, pp. 879-903.

Powell, T.C. (1995), "Total quality management as competitive advantage: a review and empirical study", Strategic Management Journal, Vol. 16, pp. 15-37.

Powell, T.C. (2001), "Competitive advantage: logical and philosophical considerations", Strategic Management Journal, Vol. 22, pp. 875-888.

Porter, M.E. (1980), Competitive Strategy, Free Press, New York.

Rao, S.S. Solis, L.E. and Raghunathan, T.S. (1999), “A framework for international quality management research: development and validation of a measurement instrument", Total Quality Management, Vol. 10, pp. 1047-1075.

Raykov, T. and Marcoulides G.A. (2006), A First Course in Structural Equation Modelling. Psychology Press, London.

Reed, R., Lemak, D.J. and Mero, N.P. (2000), "Total quality management and sustainable advantage", Journal of Quality Management. Vol. 5, pp. 5-26.

Rumelt, R. (1991), "How much does industry matter?" Strategic Management Journal, Vol. 12, pp. 167-185. 
Sharma, B. and Gadenne, D. (2008), "An empirical investigation of the relationship between quality management factors and customer satisfaction, improved competitive position and overall business performance", Journal of Strategic Marketing, Vol. 16, pp. 301-314.

Sheehan, M. (2014), "Human resource management and performance: Evidence from small and medium-sized firms", International Small Business Journal, Vol. 32, pp. 545-570.

Shenawy, E.E., Baker, T. and Lemak, D.J. (2007), "A meta-analysis of the effect of TQM on competitive advantage", International Journal of Quality and Reliability Management, Vol. 24,pp. 442-471.

Sila, I. and Ebrahimpour, M. (2005), "Critical linkages among TQM factors and business Performance", International Journal of Operations and Production Management, Vol. 24, pp.1123-1155.

Sirmon, D.G., Hitt, M.A., Arregle, J. and Campbell, J.T. (2010), "The dynamic interplay of capability strengths and weaknesses: investigating the bases of temporary competitive advantage", Strategic Management Journal, Vol. 31, pp.1386-1409.

Sousa, R. and Voss, C.A. (2002), "Quality management revisited: a reflective review and agenda for future research", Journal of Operations Management, Vol. 20, pp. 91-109.

Statistical Solutions (2015), "Power and Sample Size Calculator", http://www.statisticalsolutions.net/pss_calc.php

Tabachnick, B. and Fidell, L. (2007), Using Multivariate Statistics. Pearson Education Inc. and Allyn \& Bacon, Boston, MA.

Talib, F., Rahman, Z. and Qureshi, M.N. (2011), "Prioritizing the practices of total quality management: An analytic hierarchy process analysis for the service industries", Total Quality Management \& Business Excellence, Vol. 22, pp.1331-1351.

Tang, Y.C. and Liou, F.M. (2010), "Does firm performance reveal its own causes? The role of Bayesian Inference", Strategic Management Journal, Vol. 3, pp. 39-57.

Tari, J., Molina, J.F. and Castejon, J.L. (2007), "The relationship between quality management practices and their effects on quality outcomes", European Journal of Operational Research, Vol. 183, pp. 483-501.

Teece, D.J., Pisano, G. and Shuen, A. (1997), "Dynamic capabilities and strategic management”, Strategic Management Journal, Vol. 18, pp. 509-533.

Thomas, J.D. and Ryman, J.A. (2003), "Understanding competitive advantage in the general hospital industry: evaluating strategic competencies", Strategic Management Journal, 24, pp. 333-347.

Yusuf, Y., Gunasekaran, A. and Dan, G. (2007), "Implementation of TQM in China and organization performance: An empirical investigation”, Total Quality Management, Vol. 18, pp. 509-530.

Wagner, S.M. (2006), “A firm's responses to deficient suppliers and competitive advantage”, Journal of Business Research, Vol. 59, pp. 686-695.

Wang, Z., Qiu, Y. and Gui, S. (2006), "Quality competence: a source of sustained competitive advantage", The Journal of China Universities of Posts and Telecommunications, 13, pp. 104-108.

Wernerfelt, B. (1984), “A resource-based view of the firm”, Strategic Management Journal, Vol. 5, pp. 171-180.

Wolf, E.J., Harrington, K.M., Clark, S.L., and Miller, M.W. (2013), "Sample size requirements for structural equation models: An evaluation of power, bias and solution propriety". Educational and Psychological Measurement, DOI:

$10.1177 / 0013164413495237$. 
Wong, W.P., Tseng, M.L. and Tan, K.H. (2014), “A business process management capabilities perspective on organisation performance", Total Quality Management \& Business Excellence, Vol. 25, pp. 602-617.

Yunis, M., Jung, J. and Chen, S. (2013), “TQM, strategy, and performance: a firm level analysis", International Journal of Quality \& Reliability Management, Vol. 30, pp. 690714. 